\title{
HARI JADI KOTA JAKARTA
}

\author{
Oleh Heru Erwantoro \\ Balai Pelestarian Sejarah dan Nilai Tradisional Bandung \\ Jln. Cinambo No. 136 Ujungberung Bandung \\ Email: heruerwantoro@ymail.com
}

\begin{abstract}
Abstrak
Sejak tahun 1956, tanggal 22 Juni ditetapkan sebagai Hari Jadi Kota Jakarta. Ironisnya, sejak itu pula, penetapan itu menjadi polemik di antara para ahli sejarah dan pengamat sejarah. Pada konteks inilah, penelitian sejarah dapat mencarikan solusi untuk mengakhiri kontroversi yang berkepanjangan.

Melalui penelitian sejarah ini, dilakukan beberapa langkah yang meliputi: (1) penelusuran literatur untuk mendapatkan data baru yang dapat dijadikan fakta baru, (2) Mengkaji kembali pendapat para ahli agar dapat diketahui akar permasalahan dari kontroversi yang selama ini terjadi, (3) dilakukan intrerpretasi baru. Dari penelitian sejarah ini, akhirnya, dapat ditemukan akar permasalahan yang sebenarnya dan dapat dicarikan solusi untuk mengakhiri kontroversi yang berkepanjangan.
\end{abstract}

Kata Kunci: Hari Jadi Kota, remembered history, invented history, recovered history, history base agreement.

\begin{abstract}
Since 1956, June 22nd was celebrated as Jakarta City's birthday. Ironically, since the beginning this matter still on dispute between the history exprets and history observer. On this context, an history research is expected to give a solution to end this prolonged controversy.

Throught this history research, there are some steps to do i.a. (1) literature investigation to get new data for proofing as new facts, (2) re-study the experts' opinion as a root of controversy, (3) choose a theory which could explain the problem, (4) get the new interpretation done. From that history research, finally there will be a real source of problem and the final solution to end this prolonged controversy.
\end{abstract}

Keywords: City's birthday, remembered history, invented history, recovered history, history base agreement.

\section{A. Pendahuluan}

Setiap tanggal 22 Juni, masyarakat dan pemerintah DKI Jakarta memperingati hari kelahiran Kota Jakarta. Menurut Djulianto Susanto sesungguhnya hari lahir Jakarta mengandung kontroversi sebab surat keputusan Dewan Perwakilan Kota Sementara Djakarta Raja pada tanggal 23 Februari 1956 didasarkan pada hasil penelitian sejarah yang belum tuntas (Kompas, Selasa 13 Juni 2006). Prof. Sukanto yang melakukan penelitian itu pun mengakui bahwa hari lahirnya Kota Jakarta yang pasti belum dapat diketahui (lihat bukunya "Dari Jakarta ke Djakarta" tahun 1954). Bila memang demikian kenyataannya, tentu saja Surat Keputusan Dewan Perwakilan Kota Jakarta itu 
berdiri pada fondasi yang goyah yang tentu saja tidak menguntungkan bagi masyarakat Kota Jakarta khususnya, dan bagi bangsa Indonesia pada umumnya. Mengapa demikian? Sebab hari jadi sebuah kota adalah momen yang penting. Hari jadi itu sendiri mempunyai mitos sebagai manifestasi dari penggabungan antara sejarah dengan praduga dan hasrat kultural. Dalam hal ini mitos berfungsi untuk memperkokoh ikatan sosial. Dengan mitos itu masyarakat dan pemerintah suatu kota mempunyai "simbol" yang dapat mempersatukan dan memberi semangat hidup sehingga kota itu dapat terus eksis dan berkembang. Berdasarkan permasalahan di atas, penelitian sejarah ini pada dasarnya mencoba mencari landasan teoretis sebagai legitimasi bagi hari lahirnya Kota Jakarta.

Menurut Abdullah (2005:1-3), dalam tradisi penulisan sejarah untuk menentukan hari jadi kota tercatat empat pola, yaitu: pola remembered history, invented history (prefabricated history), recovered history, dan history base agreement.

Pada remembered history, hari jadi kota didasarkan pada sifat historicity atau kesejarahannya. Biasanya hari jadi kota didasarkan pada pendirian kraton, benteng, atau apa saja yang tentunya dapat dianggap sebagai titik mula dari peranan sebuah settlement menjadi kota dalam pengertian sosiologis, yaitu sebagai pusat jaringan dari aktifitas sosial bagi wilayah di sekitarnya. Hal yang demikian itu, dapat terjadi sebab yang dianggap hari jadi itu masih terdapat dalam ingatan kolektif masyarakat setempat atau terekam dalam catatan. Sebaliknya, pada pola invented history atau prefabricated history, penentuan hari jadi kota acuannya justru bertentangan dengan ketentuan yang terdapat pada pola remembered history.
Pada pola invented history ini, makna historis lebih dipentingkan sehingga kepastian sejarah hanya sekadar untuk menentukan waktu saja karena yang lebih dipentingkan adalah nilai yang hendak dilekatkan pada hari jadi itu. Sebagai misal, pada penentuan hari jadi sebuah kota kebetulan tidak terdapat suatu peristiwa sejarah yang sesuai. Oleh karena itu diambil langkah menggabungkan antara tahun terjadinya peristiwa tertentu (mungkin berdirinya sebuah benteng) sebagai momen, kemudian untuk tanggal dan bulannya diambil dari hari lahir seorang pemimpin yang dikagumi. Pada konteks itu, tanggal hanyalah alat untuk merayakan suatu simbol yang bermakna. Selanjutnya, pemakaian pola recovered history banyak ditemui di kota-kota yang terdapat di Pulau Jawa dan sebagian Pulau Sumatera (terutama Palembang) yang memiliki peninggalan prasasti (yang mengandung angka tahun). Pada pola ini hari jadi diambil dari penang-galan yang terdapat di dalam prasasti. Oleh karenanya, tidaklah mengherankan bila di Pulau Jawa kita temukan kota-kota yang mengklaim diri telah berusia ratusan tahun, padahal kaitan antara kota-kota itu dengan prasasti tidak dapat dipertanggungjawabkan. Yang terakhir, pola sejarah berdasarkan persetujuan. Pada pola ini, hari jadi diambil dari sebuah peristiwa yang terjadi di daerah atau di sekitar daerah perkotaan.

Dari keempat pola tersebut di atas terlihat dengan jelas bahwa di dalam menentukan hari jadi sebuah kota terdapat keleluasaan atau kebebasan. Mengapa hal itu dapat terjadi? Jawabnya, karena sebuah kota meskipun ke-beradaannya sebagai kesatuan administratif ditentukan oleh keputusan politik, akan tetapi pada hakekatnya sebuah kota memiliki peran yang lebih dari sekadar kesatuan politik. Sebuah kota, selain sebagai sebuah 
wilayah tempat tinggal dengan segala infrastrukturnya, kota juga merupakan pusat dari berbagai jaringan (networks) yang meliputi pusat pemerintahan, pendidikan, dan sebagainya bagi wilayahwilayah di sekitarnya. Artinya, tanpa keputusan politik di dalam penentuan statusnya sebagai kota atau kotapraja (gemeente), sebuah kota dilihat dari perannya telah "kota" juga.

\section{B. Hasil dan Bahasan}

\section{Polemik Hari Lahir Kota Jakarta}

Menurut Soekanto, Faletehan merebut Sunda Kalapa pada akhir bulan Februari 1527. Beberapa hari setelah perebutan itu, datanglah armada Portugis di bawah pimpinan Francisco De Sa yang bermaksud akan membangun benteng di Sunda Kalapa. Selanjutnya, pada pertengahan bulan Maret 1527, Pasukan Faletehan menyerang armada Portugis itu dan Pasukan Faletehan berhasil mengalahkan armada Portugis. Dengan keberhasilan merebut Sunda Kalapa dan mengalahkan armada Portugis, Faletehan bermaksud mengabadikan kemenangan itu dengan mengganti nama Sunda Kalapa.

Soekanto menulis:

"Djadi: Nama Djajakarta diberikan setelah kemenangan sepenuhnja tertjapai; setelah pembunuhan dilakukan atas orang Portugis jang terdampar di Pantai di Sunda Kalapa; setelah Francisco de $\mathrm{Sa}$ dengan menderita kerugian kembali ke Malaka; djadi kira-kira setelah pertengahan bulan Maret 1527" (Soekanto, 1954: 57).

Pergantian nama Sunda Kalapa tidak langsung dilakukan setelah Faletehan menguasai Sunda Kalapa, sebab Faletehan merasa bahwa citacitanya menghancurkan Portugis belum- lah tercapai sepenuhnya. Hal yang demikian itu terbukti dari nama Jayakarta yang dipakai untuk mengganti nama Sunda Kalapa. Nama Jayakarta mempunyai arti kemenangan yang penghabisan, dapat juga berarti kemenangan yang sepenuhnya, atau juga kemenangan yang sempurna. Tentu saja, dalam pandangan Faletehan, kemenangan yang sempurna adalah menghancurkan Portugis, musuh yang sangat dibenci oleh dirinya dan oleh orang-orang muslim. Bukankah Faletehan itu sendiri adalah orang Pasai yang mempunyai dendam karena Portugis telah menguasai Pasai. Orang muslim terpaksa harus keluar dari Pasai dan mencari tempat yang lain. Rasa benci itu juga semakin bertambah ketika Kerajaan Sunda menjalin kerja sama dengan Portugis.

Selanjutnya Soekanto berpendapat bahwa Faletehan di dalam mengganti nama Sunda Kalapa dengan nama Jayakarta tidaklah memakai penanggalan Hindu-Jawa. Menurutnya, Faletehan mengambil penanggalan yang sungguhsungguh hidup di kalangan rakyat dari dahulu sampai saat itu, yaitu penanggalan yang ada hubungannya dengan pertanian. Penanggalan itu disebut pranatamangsa.

Dalam akhir pendapatnya, ia berkeyakinan bahwa nama Jayakarta sebagai pengganti nama Sunda Kalapa diberikan beberapa bulan setelah bulan Maret 1527. Secara eksplisit Soekanto menulis:

"Mengingat pula pada apa jang telah diuraikan diatas itu, jakni mangsa kesatu djatuh dalam bulan Djuni (bulan panen atau bulan setelah panen), kita kira kemungkinannja tidak sedikit, bahwa nama Djajakarta diberikan pada tanggal satu mangsa kesatu, jaitu pada bulan Djuni, tanggal 22, tahun 1527. Harinja jang pasti kita tidak dapat menemukannja (Soekanto, 1954: 60). 
Pendapat Soekanto itu mendapat tanggapan dari Hoesein Djajadiningrat. Ia berpendapat berdasarkan sumber-sumber sejarah dari pengarang-pengarang Eropa, armada Portugis di bawah pimpinan Francisco de Sa yang pergi ke Sunda Kalapa berangkat dari Malaka pada tanggal 23 Oktober 1526. Pada bulan Desember 1526 pada waktu perayaan hari Natal di Cochij (India), diperoleh kabar dari Malaka bahwa pemimpin armada itu telah kembali, dan pada penghabisan bulan Desember tersebut pembesar itu telah bertolak ke India. Berdasarkan hal itu maka jatuhnya Sunda Kalapa terjadi pada bulan Desember 1526. Setelah itu, untuk menentukan harinya, ia mencari hari raya atau hari peringatan Islam yang dekat waktunya dengan jatuhnya Sunda Kalapa pada bulan Desember 1526. Ia menduga bahwa pada hari raya Islam itu, Faletehan merayakan kemenangannya dengan gembira dan perasaan bersyukur. Adapun Hari Raya Islam yang paling dekat dengan penghabisan bulan Desember 1526 adalah hari Maulud tanggal 12 Rabiulawal 933 Hijrah, hari itu jatuh pada hari Senin tanggal 17 Desember 1526.

Dengan demikian, mungkin sekali pada hari raya itu, di kala Faletehan merenungkan kemenangannya, ia teringat pada kemenangan Nabi Muhammad yang terpenting yaitu merebut Mekah. Ia juga teringat pula pada ayat pertama dari Surat Al-Fath yang berbunyi: "Inna fatahna laka fathan mubinan" yang artinya "Sesungguhnya kami telah memberikan kemenangan kepadamu kemenangan yang tegas". Berdasarkan hal-hal itulah, Faletehan mendapatkan ilham untuk menamai dirinya "Fathan" (nama itu kemudian karena salah dengar dan salah tulis oleh orang Portugis menjadi Faletehan), kemudian nama Sunda
Kalapa digantinya dengan terjemahan "Fathan Mubinan", yaitu Jayakarta.

Pendapat Hoesein Djajadiningrat mendapat sanggahan dari Slamet Mulyana. Menurut Slamet Mulyana, Hoesein Djajadiningrat membuat spekulasi bahwa nama Faletehan itu berasal dari nama Fathan, yang diambilnya dari ayat Quran Inna fatahna laka fathan mubinan. Akan tetapi, dalam usahanya menjelaskan nama Tagaril yang disebut oleh Fernando Mendez Pinto, Hoesein Djajadiningrat menyebut nama Fakhrillah sebagai nama pribadinya, padahal penyebutan Tagaril itu dilakukan 20 tahun setelah panglima Demak itu menguasai Banten dan Sunda Kalapa. Jadi, pada waktu itu panglima Demak itu telah mengambil nama Fathan, seandainya teori di atas benar.

Slamet Mulyana merujuk sumber sejarah lokal Purwaka Caruban Nagari yang menguraikan dengan jelas bahwa Panglima Demak berasal dari Pasai dan berhasil menguasai Banten dan Sunda Kalapa pada tahun 1526 dan 1527, bernama Fadillah Khan. Nama itu berulangkali disebut dalam Purwaka Caruban Nagari. Dalam pendengaran orang Portugis nama Fadillah Khan dapat menjadi Faletehan. Bunyi nama itu memang mirip sekali dengan Faletehan, sedangkan peristiwa sejarah yang diuraikan oleh Joao de Barros memang sama tepat dengan peristiwa sejarah yang diuraikan dalam Purwaka Caruban Nagari. Atas dasar itu dapat diambil kesimpulan, bahwa Faletehan ialah transliterasi Portugis dari nama asli Fadillah Khan. Seperti telah diuraikan di atas, nama Tagaril juga dapat dijelaskan sebagai transliterasi Portugis dari nama Fadil-(lah), jika ditinjau dari pendengaran orang asing. Nama Faletehan terbukti berasal dari nama asli Fadillah Khan, yang sama sekali tidak ada hubungannya dengan ayat Quran. Oleh sebab itu, 
timbullah pertanyaan, apakah masih akan dipertahankan teori yang mengatakan bahwa nama Jayakarta itu berasal dari terjemahan fathan mubinan, yang diambil dari ayat Quran?

Selanjutnya, Slamet Mulyana merumuskan bantahannya sebagai berikut: Pertama, seperti telah disinggung di muka nama Fathan yang diambil dari ayat Quran ialah spekulasi Hoesein Djajadiningrat untuk menjelaskan nama Faletehan yang disebut dalam sumber sejarah Portugis. Dari uraian Purwaka Caruban Nagari terbukti bahwa panglima Demak yang berhasil menguasai Sunda Kalapa pada tahun 1527 bernama Fadillah Khan. Nama lengkapnya menurut sumber sejarah lokal tersebut ialah Maulana Fadillah Khan Ibnu Maulana Makhdar Ibrahim alGujarat. Nama Fadillah Khan ialah nama pribadinya sejak ulama itu masih tinggal di Pasai. Jadi panglima tentara Demak itu, sesudah menguasai Sunda Kalapa pada tahun 1527 , tidak mengambil nama baru yang didasarkan atas kutipan ayat Quran. Nama Fathan ialah sebagian dari nama fathan mubinan dari ayat Quran Inna fatahna laka fathan mubinan. Oleh karena kata fathan tidak diambil sebagai nama baru oleh panglima tentara Demak, maka kata fathan mubinan juga tidak diambil sebagai nama untuk mengganti nama Sunda Kalapa.

Kedua, Sumber sejarah lokal Purwaka Caruban Nagari sama sekali tidak menyinggung pergantian nama Sunda Kalapa menjadi Jayakarta. Sesudah Sunda Kalapa dikuasai oleh tentara Islam dari Demak, sejarah lokal tetap menyebut Sunda Kalapa. Penyebutan itu berlaku sampai akhir abad ke-16. Satu kali saja sejarah lokal itu menyebut nama Jayakarta, yakni dalam uraiannya tentang serangan Mataram pada tahun 1628 terhadap Jayakarta atas perintah Sultan Agung. Ini berarti bahwa penggubah Purwaka Caruban Nagari mengetahui tentang adanya pergantian Sunda Kalapa menjadi Jayakarta, namun pergantian nama itu tidak dilakukan oleh Fadillah Khan segera setelah menguasai Sunda Kalapa.

Ketiga, Baik di Pasai maupun di Demak, Fadillah Khan hidup dalam masyarakat Islam. Bagi ulama Islam seperti Fadillah Khan, nama Arab lebih cocok daripada nama Sansekerta. Seandainya ia memberi nama baru sebagai ganti nama Sunda Kalapa, ia akan memilih kata Arab atau nama kota di Arabia atau Negara Islam lainnya. Pilihan nama yang demikian cocok dengan semangat Islam. Di Demak sendiri ia menyaksikan pergantian nama dari Gelagah Wangi/Bintoro menjadi Demak, setelah Jin Bun atau Raden Patah sepenuhnya menguasai daerah tersebut. Berdasarkan analogi itu pergantian nama Sunda Kalapa menjadi Jayakarta tidak sesuai dengan semangat Islam. Keempat, alasan utama yang mendorong untuk menghubungkan nama Jayakarta dengan kemenangan tentara Islam di Sunda Kalapa pada tahun 1527 ialah karena dalam toponim Jayakarta terdapat unsur jaya yang berarti kemenangan. Tidak semua toponim dan nama orang yang mengandung unsur jaya dapat dihubungkan dengan suatu kemenangan dalam riwayat kehidupannya. Nama Kota Jasinga, berasal dari Jayasinga seperti Jakarta berasal dari Jayakarta, masih diragukan, apakah nama itu dapat dihubungkan dengan suatu kemenangan. Ada kalanya demikian, misalnya pergantian nama Sukarnopura menjadi Jayapura sesudah jatuhnya pemerintahan Sukarno pada tahun 1967. Nama orang dengan unsur jaya seperti Jayanagara, raja Majapahit, tidak ada hubungannya dengan suatu kemenangan.

Kembali lagi pada Carita Purwaka Caruban Nagari, diceritakan bahwa Ki 
Bagus Angke mempunyai putra bernama Sungarasa Jayawikarta. Menurut Slamet Mulyana, nama itu sangat menarik sebab nama Jayawikarta juga dicatat dalam babad lokal sejarah Banten (lihat Uka Tjandrasasmita, 1977: 69), milik Haji Gogo Sanjadirdja mantan Bupati Serang, bertarikh 1206 H (1794 M). Menurut Slamet Mulyana, nama Wijayakrama ialah nama abhiseka Pangeran Jayawikarta atau Pangeran Wijayakarta. Untuk orang biasa, pengambilan nama abhiseka berlangsung setelah menikah; adapun bagi seorang pembesar pengambilan nama abhiseka berlangsung setelah wisuda. ${ }^{1}$

Dari gambaran di atas, atas dasar analogi, Slamet Mulyana kemudian mengatakan bahwa Jayawikarta atau Wijayakarta setelah diwisuda sebagai Bupati Sunda Kalapa menggantikan ayahnya Ki Bagus Angke, mengambil nama abhiseka Wijayakrama. Perangkapan nama kecil dengan nama abhiseka sudah biasa terjadi, misalnya: Dyah Hayam Wuruk Sri Rajasanagara; Tribhuwanatunggadewi Jayawisnuwardhani dan sebagainya. Maka tidaklah mengherankan jika Wijayakarta atau Jayawikarta setelah diwisuda bergelar Pangeran Jayakarta Wijayakrama.

Bila di atas telah diuraikan bahwa nama tempat dapat melekat pada nama orang, maka di sini akan dikemukakan pula adanya kecenderungan nama orang dipakai menjadi nama tempat. Perubahan

\footnotetext{
1 Setelah Dyah Hayam Wuruk diwisuda sebagai pembesar di Kahuripan, ia mengambil nama abhiseka Sri Rajasanagara. Nama abhiseka ini dipertahankan sampai ia menjadi raja Majapahit dari tahun 1351 sampai 1389. Sebelumnya, Sanggramawijaya, pendiri kerajaan Majapahit, setelah diwisuda pada tahun 1294, mengambil nama abhiseka Kertarajasa Jayawardhana. Begitu pula, Pangeran Darajatun setelah diwisuda sebagai SultanYogyakarta, ia mengambil nama abhiseka Hamengku-buwana IX.
}

nama pribadi menjadi toponim sebagian besar didasarkan pada penonjolan pembesar atau tokoh yang menetap di daerah yang bersangkutan atau menguasai tempat yang bersangkutan. ${ }^{2}$

Atas dasar uraian itu, maka Slamet Mulyana berpendapat bahwa tidaklah mustahil toponim Jayakarta sebagai pengganti toponim Sunda Kalapa, semula adalah nama pribadi pembesar yang menguasai Sunda Kalapa yakni Pangeran Wijayakarta/Jayawikarta. Perkembangan toponim itu lalu seperti berikut: dari Jayawikarta menjadi Wijayakarta; dari Wijayakarta menjadi Jayakarta; kemudian dari Jayakarta menjadi Jakarta. Seandainya pertimbangan itu dapat diterima, itu artinya perubahan nama Sunda Kalapa menjadi Jayakarta, berlangsung pada akhir abad ke-16, pada saat Pangeran Jayakarta mulai menetap di Sunda Kalapa. Selanjutnya, dari sumber berita Kompeni Belanda dapat diketahui bahwa tempat kediaman Pangeran Jayakarta adalah di belakang Pelabuhan Sunda Kalapa, di tepi Sungai Ciliwung.

2 Dalam sejarah banyak contohnya. Misalnya, di daerah Surakarta terdapat kampung yang bernama Kusumayudan, Kusuma-diningratan, Margayudan, Secayudan, kemudian di daerah Yogyakarta terdapat kampung Yudanegaran dan Bratakesuman. Nama-nama kampung itu diambil dari nama pembesar yang pernah menetap di atau menguasai tempat yang bersangkutan yakni: Pangeran Kusumayuda, Pangeran Kusumadiningrat, Pangeran Margayuda, Pangeran Secayuda, Bupati Yudanegara, dan Pangeran Brata Kusuma. Contoh yang lain lagi ialah: Nama Sukarno digunakan untuk mengganti nama Kota Hollandia di Irian Jaya, ketika Irian kembali ke dalam wilayah Republik Indonesia. Kota Hollandia itu lalu disebut Sukarnopura artinya Kota Sukarno. Di Rusia kita kenal Kota Petersburg yang kemudian diganti dengan Leningrad artinya Kota Lenin, dan Stalingrad artinya Kota Stalin. Kemudian pada abad ke-7 di Kamboja ada kota Isanapura, karena ibokota itu dibangun oleh raja Kamboja yang bernama Isanawarman. 
Tempat itulah yang mula-mula disebut Jayakarta, sebab tempat itu merupakan tempat kediaman Pangeran Jayakarta. Bagian itu merupakan inti kota. Dari tempat itu kemudian berkembang kota Jayakarta di sepanjang Sungai Ciliwung.

Mengenai persoalan tarikh tentang perubahan nama Sunda Kalapa menjadi Jayakarta, Slamet Mulyana kemudian merujuk pada sumber sejarah Portugis Livro de Marinhara pada tahun 1527, yang masih menyebut Sundabamta untuk Sunda Banten dan Sundacalapa untuk Sunda Kalapa. Seandainya perubahan nama Sunda Kalapa menjadi Jayakarta itu telah terjadi pada tanggal 17 Desember 1526 atau pada 22 Juni 1527 seperti dinyatakan oleh kedua pakar di atas, kiranya J. de Lisboa akan menyebut nama Jayakarta dalam karyanya yang berjudul Livro de Marinhara itu. Begitu juga dengan sumber sejarah lokal Purwaka Caruban Nagari yang ditulis pada tahun 1720 Masehi, tetap menyebut toponim Sunda Kalapa sampai akhir abad ke-16. Dalam karya itu dikatakan bahwa Pangeran Pasai (Faletehan) diangkat menjadi Bupati Sunda Kalapa dan kekuasaan Pangeran Hasanuddin pada tahun 1568 meliputi Sunda Kalapa, karena Bupati Sunda Kalapa Bagus Angke, adalah seorang menantu Sultan Banten.

Menurut Slamet Mulyana, toponim Jayakarta muncul dalam prasasti yang berasal dari Banten. Untuk jelasnya perhatikan tulisan Van der Tuuk berikut ini:

"Di dalam piagam dari Banten selalu saya dapati istilah wong encik untuk menyebut orang Melayu. Istilah ini sangat menarik perhatian, karena hal itu membuktikan bahwa istilah wong Melayu pada waktu itu mengandung hinaan. Bangsa lain yang datang dengan perahu, dalam piagam itu disebut wong masin. Mula-mula saya kira bahwa istilah itu kata Melayu asing, tetapi ternyata istilah wong masin yang dijumpai, selalu ditulis dengan $n$ saja. Oleh karena itu saya berpendapat bahwa istilah itu memang benar wong masin. Di dalam piagam yang lebih muda .... Saya jumpai istilah wong Jakerta, dan wong Jayakerta.... (H.N. van der Tuuk. TBG. XIX. 1870).

Adanya toponim Jakerta dan Jayakerta pada prasasti-prasasti yang berasal dari Banten itu benar-benar menarik perhatian, karena hal itu memberikan petunjuk ke arah pemecahan soal. Hal itu merupakan bukti nyata bahwa toponim Jayakarta telah ada sebelum kedatangan orang Belanda. Tarikh prasasti Banten yang menyebutkan wong Jaketra itu dapat dijadikan pegangan untuk menetapkan hari lahir Jayakarta. Akan tetapi, sayangnya bagian yang menyatakan tarikh itu robek, sehingga tidak dapat diketahui tarikhnya. Meskipun demikian, dari isinya dapat diketahui, bahwa piagam Banten itu dikeluarkan pada awal abad ke-17, karena di dalam piagam itu telah tercantum kata kumendur, yang berasal dari kata Belanda atau Inggris Commander. Dengan begitu, boleh dipastikan bahwa piagam itu dikeluarkan setelah tahun 1602, ketika orang Belanda telah datang ke Indonesia.

Adapun piagam Banten yang menyebut wong Jaketra bunyinya sebagai berikut:

"Lamon ana wong Djaketra angambil daon atawa kaju atawa angambil wiru, iku aweja rubaruba adjen-adjen sarejal; lamon sih wong Djaketra iku ora anggawa tjap dalem lan surate kumendur, iku tjegahen patjuwan den wehi mandjing ing muwara Putih (op de 
kaart Saputih); lamon maksa ora kena den tjegah, den gelis-gelis matura ing Bumi olija den sih....." Artinya sebagai berikut:

Jika ada orang Jakarta mengambil daun atau kayu atau mengambil wiru; supaya memberikan uang pengganti. Jika orang Jakarta itu tidak membawa cap istana dan surat dari kumendur, supaya ditolak dan dimasukkan ke dalam muara Sungai Putih (Saputih). Jika ia memaksa dan tidak mau ditolak, supaya segera memberi tahu Mangku Bumi....

Sumber lain yang menyebutkan toponim Jayakarta ialah Laporan Cornelis de Houtman pada tanggal 14 November 1596. Cornelis de Houtman ikut serta dalam rombongan pertama orang-orang Belanda yang berlayar ke Indonesia pada tahun 1595. Dalam laporan itu Cornelis de Houtman menyebut bahwa Pangeran Wijayakrama, nama wisuda Pangeran Sungarasa Jayawikarta, koning van Jacatra, artinya, raja Jakarta (lihat Jhr. Mr. K. J. de Jonge, De opkomst van het Nederlandsche gezag in Oost-Indie 1595-1610. Jilid 1.'s Gravenhage. 1862). Dari laporan itu nyata bahwa nama Jacatra atau Jakarta pada tahun 1596 telah menjadi nama tempat atau nama kota. Tarikh laporan Cornelis de Houtman bertepatan dengan masa pemerintahan Pangeran Sungarasa Jayawikarta. Penguasa ini biasa disebut Pangeran Jayakarta. Sebutan itu dapat ditafsirkan Pangeran yang menguasai Jayakarta atau Pangeran yang bernama Jaya (wi) karta. Yang pertama mengandung pengertian nama tempat; yang kedua mengandung pengertian nama orang.

\section{Analisis}

Dari pendapat ketiga pakar yang telah diuraikan di atas kita masih belum mendapat kepastian mengingat adanya berbagai perbedaan dalam menentukan tanggal, bulan, dan tahun kelahiran kota Jakarta.

Dari uraian di atas sekarang dapat ditelusuri penyebab terjadinya perbedaan tahun jatuhnya Sunda Kalapa ke tangan Faletehan yang terjadi antara Soekanto dengan Hoesein Djajadiningrat. Ternyata, Hoesein Djajadiningrat memakai sumber sejarah Portugis yang menerangkan bahwa Francisco de Sa telah berangkat dari Sunda Kalapa ke Malaka pada tanggal 23 Oktober 1526 dan kemudian meneruskan perjalanan ke Cochij, tiba di Cochij pada tanggal 25 Desember 1526 seterusnya berlayar kembali menuju Goa India. Apa yang didapatkan oleh Hoesein Djajadiningrat itu memang benar, Fancisco de Sa sudah meninggalkan Sunda Kalapa pada tahun 1526 dan ia menuju ke Goa India untuk menduduki jabatan sebagai Gubernur Goa. Yang perlu dicatat pada saat Francisco de Sa meninggalkan Sunda Kalapa, Sunda Kalapa belum diserang apalagi dikuasai oleh pasukan Demak di bawah pimpinan Faletehan. Sayangnya, Hoesein Djajadiningrat tidak memperoleh sumber sejarah yang mendiskripsikan peristiwa selanjutnya. Peristiwa kepergian Francisco de Sa dari Goa India menuju Sunda Kalapa pada tahun 1527 untuk membantu Kerajaan Sunda bila diserang musuh sesuai dengan perjanjian yang telah disepakati oleh Portugis dan Kerajaan Sunda yang tidak didapatkan oleh Hoesein Djajadiningrat. Dengan jelas, dapatlah dikatakan bahwa pelabuhan Sunda Kalapa dapat direbut oleh pasukan Faletehan terjadi pada tahun 1527.

Dari ketiga orang pakar di atas yang mengajukan tanggal dan bulan kelahiran untuk dijadikan tanggal dan bulan kelahiran kota Jakarta hanya dua pakar. Menurut Soekanto, tanggal dan 
bulan yang tepat untuk dijadikan tanggal dan bulan bagi kelahiran Kota Jakarta ialah tanggal 22 dan bulan Juni. Sedangkan Hoesein Djajadiningrat berpendapat hari, tanggal, dan bulan yang tepat untuk dijadikan hari, tanggal, dan bulan kelahiran Kota Jakarta ialah hari Senin, tanggal 17, dan bulan Desember. Berbeda dengan kedua pakar tersebut, Slamet Mulyana justru tidak berani untuk mengajukan hari, tanggal, bulan, dan tahun bagi kelahiran Kota Jakarta.

Hoesein Djajadiningrat (berdasarkan sumber asing) menjelaskan bahwa Armada Portugis di bawah pimpinan Francisco de Sa pada tanggal 23 Oktober 1526 telah berangkat dari Malaka menuju Sunda Kalapa. Kemudian pada bulan Desember 1526 tepatnya pada perayaan hari Natal (25 Desember 1526) armada itu telah sampai di Cochij, India. Selanjutnya, pada akhir bulan Desember armada itu berangkat menuju Goa, India. Yang luput dari perhatian Hoesein Djajadiningrat ialah bahwa pada tahun 1526 itu belum terjadi pertempuran antara pasukan Demak dibawah pimpinan Faletehan dengan armada Portugis. Hoesein Djajadiningrat begitu membaca sumber yang mengatakan bahwa Francisco de Sa berada di India pada bulan Desember 1526, ia lalu berkesimpulan bahwa pertempuran telah terjadi dan telah selesai.

Dari uraian Saleh Danasasmita, dkk, (1983/1984: 20-23) kita dapat memahami berita yang mengatakan bahwa Franciso de Sa tiba di India pada tahun 1526 memang benar. Keberadaan Francisco de Sa di sana untuk memangku jabatan Gubernur di Goa, India. Oleh sebab itulah ketika Sunda Kalapa mendapat serangan dari pasukan Demak, bantuan dari Portugis datangnya terlambat. Dari Goa, Francisco de Sa mempersiapkan keberangkatannya ke Sunda Kalapa dengan 6 buah kapal menuju Malaka. Akan tetapi, armada itu diterpa badai di Teluk Benggala sehingga Galium yang dinaiki Francisco de Sa dan memuat peralatan untuk pembangunan benteng terpaksa ditinggalkan. Francisco de Sa tiba di Malaka tahun 1527 dan mempersiapkan keberangkantan ke Sunda. Sekarang menjadi jelas bahwa pertempuran antara armada Portugis dengan pasukan Demak di bawah pimpinan Faletehan terjadi pada tahun 1527.

Dengan demikian, bila tahun jatuhnya Sunda Kalapa ke tangan Faletehan yang diajukan oleh Hoesein Djajadiningrat dapat dipatahkan, maka secara otomatis hari, tanggal, dan bulan yang diajukannya juga dapat digugurkan.

Sekarang bagaimana dengan tanggal dan bulan yang diajukan oleh Soekanto, yaitu tanggal 22 dan bulan Juni. Apakah tanggal 22 dan bulan Juni dapat diterima sebagai tanggal dan bulan kelahiran Kota Jakarta?

Dapatkah persoalan yang rumit ini dipecahkan? Lagi-lagi kita mendapatkan titik terang dari sumber lokal, Pustaka Nusantara III/I dalam (Danasasmita, 1983/1984: 21) yang menjelaskan:

De Sa tiba di Malaka tahun 1527 dan mempersiapkan keberangkatan ke Sunda. Armada De Sa mulamula menuju Banten tetapi kekuasaan di sana telah beralih ke tangan Hasanudin. Armada Portugis ini lalu berbalik menuju Kalapa. Di muara Cisadane armada tersebut berhenti tanggal 30 Juni 1527 dan De Sa memancangkan batu padrao. Ia memberikan nama kepada Cisadane: Rio de Sa Jorge.

Dari muara Cisadane rombongan De Sa memisahkan diri lalu menuju Malaka. Hanya sebuah brigatin yang dipimpin oleh Duarte Coelho yang melanjutkan pelayarannya ke pelabuhan Kalapa. 
Coelho terlambat mengetahui perubahan situasi sehingga kapalnya menepi terlalu dekat ke pantai. Kapalnya segera dikepung oleh pasukan Fadillah. Dengan kerusakan berat dank urban yang banyak, Coelho masih berhasil meloloskan kapalnya lalu menuju ke Pasai.

Dari embaran di atas, kita dapatkan tanggal yang pasti yaitu tanggal 30 Juni 1527. Pada tanggal itu terjadi dua peristiwa: pertama, De Sa atau Fancisco de Sa di muara Sungai Cisadane memancangkan batu padrao dan memberi nama Cisadane dengan nama Rio de $\mathrm{Sa}$ Jorge kemudian kembali ke Malaka. Kedua, Armada Portugis yang dipimpin oleh Duarte Coelho menuju Sunda Kalapa dan dipukul mundur oleh pasukan Faletehan di Sunda Kalapa. Dengan tanggal ini, tentunya tidaklah diperlukan interpretasi yang spekulatif sebagaimana yang dilakukan oleh Soekanto dan Hoesein Djajadiningrat. Dapatlah dipastikan dari muara Cisadane ke pelabuhan Sunda Kalapa tidak memerlukan waktu yang lama, artinya pada hari itu juga armada Portugis yang dipimpin oleh Duarte Coelho sampai di Sunda Kalapa dan pada hari itu juga mendapat serangan dan kabur mening-galkan Sunda Kalapa. Tidak berlebihan jika pada hari itu juga, yaitu tanggal 30 Juni 1527 pasukan Faletehan merayakan kemenangannya.

Ketiga pakar membahas masalah pergantian nama dari Sunda Kalapa menjadi Jayakarta. Marilah kita coba telusuri dari mana datangnya nama Jayakarta itu. Mari kita perhatikan apa yang ditulis oleh Saleh Danasasmita, dkk. (1983/1984) berikut ini:

Fadillah menikah dengan Ratu Pembayun janda Pangeran Jayaklana kemudian memperistri
Ratu ayu janda Pangeran Sabrang Lor. Dengan kedua pernikahan tersebut, Fadillah menjadi menantu Raden Patah dan Susuhan Jati Cirebon....(halaman 20).

Di front timur timbul perkembangan baru, Ratu Galuh, Jayaningrat, melihat kekuasaan pusat di Pakuan sudah lemah...(halaman 22).

Serangan Galuh ke Cirebon terjadi dalam tahun 1528, Pasukan penyerang ini dihadang oleh pasukan Adipati Kuningan, Suranggajaya, di dekat Bukit Gundul. Suranggajaya adalah putera Ki Gendeng Luaragung, Jayaraksa (halaman 22).

Sesungguhnya Pakuan telah "berhenti berfungsi" sebagai ibukota kerajaan sejak Nilakendra meninggalkannya. Raja Pajajaran terakhir berkedudukan di Palasari, Pandenglang. Di sinitulah sesungguhnya kekuasaan raja pajajaran terakhir. Kehadiran raja Pajajaran di Pulasari dapat disamakan dengan kehadiran raja Galuh, Jayaningrat, di Talaga setelah ia dikalahkan dalam pertempuran tahun 1528 oleh pasukan Cirebon....(halaman 35).

... Jayaperkosa melihat tokoh muda Geusan Ulun sebagai tumpuan untuk melanjutkan citacitanya untuk menegakan kembali kekuasaan dan kebesaran Pajajaran... (halaman 59).

Berbagai embaran di atas jelas memperlihatkan bahwa pemakaian kata "jaya" pada masa itu merupakan sesuatu yang umum terjadi di kalangan elit kerajaan, baik itu untuk nama orang, seperti, Jayaklana, Jaya Ningrat, Jaya Raksa, dan Jaya Perkosa; maupun untuk 
nama tempat seperti Jayagiri dan Jalagrahan.

Dengan demikian, kita dapat memahami kemunculan kata "jayakarta" itu. Kata jayakarta kemungkinan besar muncul setelah Faletehan diangkat menjadi bupati Sunda Kalapa. Sistem politik yang berlaku pada masa itu memungkinkan kedudukan bupati sebagai raja juga. Sudah menjadi tradisi pada masa itu, apabila seseorang menjadi raja mendeklarasikan nama baru, begitu juga dengan Faletehan. Dalam upaya mencari nama baru untuk dirinya itu, ia sangat akrab dengan kata "jaya". Bukankah istrinya, yang bernama Ratu Pembayun itu adalah janda dari Pangeran "Jaya" Klana. Sebagai raja Sunda Kelapa, ia pun mencari legitimasi agar dapat diterima oleh rakyat Sunda dengan jalan memakai nama yang mirip dengan raja-raja Sunda terdahulu. Bukankah di Kerajaan Sunda ada raja yang bernama; Rakeyan Jayagiri (916-942 M), Sri Jayabupati/Detya Maharaja (1030-1042 M), dan Rakeyan Jayagiri Prabu Menak Luhur (1155-1157 M). Faletehan merasa cukup pantas untuk memakai nama yang mirip-mirip dengan raja Sunda terdahulu, sebab bukankah ia sendiri adalah keponakan sekaligus menantu Sunan Gunung Jati, di mana Sunan Gunung Jati itu sendiri adalah cucu dari raja Sunda.

Dapat dikatakan setelah menjadi raja di Sunda Kalapa, Faletehan bergelar Pangeran Jayakarta. Dengan demikian, sekarang menjadi jelas mengapa Purwaka Caruban Nagari tetap menyebut Sunda Kalapa sampai akhir abad ke16, karena memang Faletehan tidak pernah mengganti Sunda Kalapa dengan nama Jayakarta. Jayakarta adalah nama diri Faletehan setelah ia menjadi raja di Sunda Kalapa.

Bila begitu bagaimana dengan

pandangan Slamet Mulyana yang mengatakan bahwa toponim Jayakarta berasal dari nama Pangeran Wijayakarta/ Jayawikarta, dengan proses sebagai berikut: dari Jayawikarta menjadi Wijayakarta; dari Wijayakarta menjadi Jayakarta; dari Jayakarta menjadi Jakarta. Pendapat Slamet Mulyana itu terasa mengada-ada. Bukankah ia sendiri memberikan contoh bila nama diri dijadikan nama tempat tidaklah melalu proses yang bertahap-tahap, biasanya sederhana sekali. Hal itu biasa terjadi karena yang memberi nama biasanya rakyat dan prosesnya berjalan secara alami, informal tanpa seremoni. Kampung Yudanegaran berasal dari pembesar yang bernama Yudanegara, Kampung Secayudan berasal dari nama Pangeran Secayuda dan sebagainya. Mengapa dari Jayawikarta menjadi Wijayakarta tidak menjadi Jayawikartan saja? Mengapa juga dari Jayawikarta tidak berubah menjadi Jayawikartapura?

Oleh karena itu, rasanya tidak perlulah mengada-adakan. Marilah kita perhatikan uraian Husein Djajadiningrat yang mencuplik sumber Portugis tentang kondisi kerajaan Sunda:

Tentang kerajaan Sunda yang kecil, tetapi sedang berkembang itu, yang banyak mengeluarkan lada di mana rajanya mencari persahabatan dengan orang Portugis, telah dapat diceritakan oleh Barbosa (1516). Barros pun mengatakan bahwa setelah direbutnya Malaka oleh Alfonso d'Alboquergue pada tahun 1511, maka Sangiang Sunda sebagai mana raja-raja Indonesia lainnya mengadakan hubungan dengan orang Portugis. Dalam uraian umumnya tentang Sunda, ia menceritakan kekhususan-kekhususan yang berikut. Pedalaman lebih bergunung-gunung daripada pedalaman Jawa. Pelabuhanpelabuhan yang utama enam 
jumlahnya, yaitu Chiamo, Xacatra, yang juga disebut Caravan, Tangaram, Cheguide, Pondang, dan Bantam, dengan pelabuhan mana orang Portugis mempunyai lalu lintas perdagangan (Hoesein Djajadiningrat, 1983: 83).

Dari lembaran itu kita mendapatkan toponim Xacatra yang juga disebut Caravan. Yang dimaksud Caravan oleh sumber Portugis itu adalah pelabuhan Karawang. Pada masa lalu orang kalau hendak melakukan perjalanan ke Karawang harus selalu berkelompok untuk keamanan. Rombongan-rombongan semacam itu dalam bahasa Portugis disebut Caravan. Akan tetapi, penduduk setempat tidak mau menggunakan toponim Xacatra maupun Caravan, mereka lebih senang menyebut Karawang. Toponim Karawang itu berasal dari kata Ka-rawa-an, karena daerahnya yang berawa-rawa. Dari ka-rawa-an menjadi Karawang, hal ini didorong lebih kepada kemudahan mengucapkan dan keindahan bunyi.

Dengan dikuasainya Sunda Kalapa oleh Faletehan yang bergelar Pangeran Jayakarta itu, maka secara lambat laun toponim Xacatra hidup kembali. Orang Portugis menyebut Sunda Kalapa dengan nama Jacatra. Penduduk Sunda Kalapa dan Banten menyebut Sunda Kalapa dengan nama Jayakerta dan Jakerta, serta menyebut orang Sunda Kalapa dengan wong Jakerta atau wong Jayakerta. Orang Belanda pada masa Pangeran Wijayakrama, menyebut Pangeran Wijayakrama dengan sebutan "koning van Jacatra".

\section{Penutup}

Menurut pendapat kami, toponim Jakarta muncul secara alami, tumbuh dan berkembang di masyarakat. Dengan demikian, tentu saja tidak dapat ditentukan secara eksak kapan waktu terjadinya perubahan nama dari Sunda Kalapa menjadi Jayakarta. Kemunculan toponim Jayakarta itu dipicu setelah Faletehan memakai gelar Pangeran Jayakarta pasca ia diangkat sebagai bupati di Sunda Kalapa.

Setelah berbagai hal yang selama ini menjadi bagian dari kontroversi dapat dicarikan solusinya, sekarang marilah kita letakkan apa yang telah kita peroleh itu pada teori tentang penentuan hari jadi unit administratif yang dikemukakan oleh Taufik Abdullah. Dalam penentuan hari jadi kota, ada dua hal yang perlu diperhatikan, pertama; adalah kondisi objektif sebuah kota yang biasanya tumbuh begitu saja tanpa kita tahu bagaimana mulanya; kedua, hari jadi senantiasa dikaitkan dengan nilai sejarah dan makna simbolik (sesuatu yang berdasarkan subjektivisme kolektif). Kami sependapat dengan Taufik Abdulah yang memasukan hari jadi kota Jakarta ke dalam pola berdasarkan persetujuan. Taufik Abdulah (2005: 2) mengatakan:

"Yang paling menarik ialah kasus keempat. Sebuah peristiwa yang membanggakan yang terjadi di daerah atau sekitar daerah perkotaan diambil sebagai hari jadi kota. Saya kira yang paling berhasil dalam hal ini ialah Jakarta. Kemenangan Fatahillah melawan Portugis dan menukar nama Kalapa menjadi Jayakarta - kota kemenangan - dijadikan sebagai hari jadi kota. Bahwa tanggal pasti pergantian nama Kalapa menjadi Jayakarta itu masih bisa diperdebatkan - almarhum

Prof.DR. Husein Djajadiningrat umpamanya menyangsikan ketetapan tanggal yang diusulkan Prof. Dr. Sukanto, yang telah terlanjur disetujui DPRD Jakarta-tidak menjadi halangan karena peristiwanya cocok dengan hasrat 
simbolik Jakarta sebagai kota kemenangan..."

Dengan demikian, di dalam penentuan hari jadi kota Jakarta titik tumpunya bukan pada kapan terjadinya peristiwa pergantian nama dari Sunda Kalapa menjadi Jayakarta. Dapatlah disimpulkan bahwa hari lahir Kota Jakarta yang telah ditetapkan oleh Dewan Perwakilan Kota Sementara Djakarta Raja pada tanggal 23 Februari 1956 telah berdiri pada landasan yang benar, yaitu bertumpu pada peristiwa kemenangan yang diperoleh oleh Faletehan pada tanggal 30 Juni 1527. Peristiwa yang diambil itu telah memenuhi hasrat simbolik bukan saja bagi Kota Jakarta sebagai "Kota Kemenangan" tetapi juga bagi bangsa Indonesia. Sebagai ibukota, Jakarta adalah milik seluruh rakyat Indonesia. Kebanggaan yang diberikan oleh Jakarta bukan hanya untuk penduduk Jakarta saja, tetapi harus diberikan kepada seluruh rakyat Indonesia.

Sekarang bagaimana dengan adanya perbedaan tanggal antara tanggal hari jadi yang telah ditetapkan, yaitu tanggal 22 Juni 1527 dengan sumber sejarah lokal yang mencatat peristiwa bersejarah itu terjadi pada tanggal 30 Juni 1527. Karena perbedaan itu tidak terlalu jauh dan tidak terlalu penting, kiranya hari lahir Kota Jakarta dapat terus menggunakan apa yang telah ditetapkan selama ini. Alasannya, tentu saja makna simbolik yang membanggakan itu.

\section{DAFTAR PUSTAKA}

Abdullah,Taufik. 2005.

"Sekitar Penentuan Hari Jadi Unit Administratif: Sekadar Sumbangan Pemikiran". Makalah Disampaikan dalam Seminar Sejarah Kaji Ulang Hari Jadi Majalengka. Diselenggarakan oleh Balai Kajian
Sejarah dan Nilai Tradisional Bandung bekerja sama dengan Masyarakat Sejarawan Indonesia Cabang Jawa Barat dan Pemerintah Daerah Kabupaten Majalengka pada tanggal 30 Agustus 2005.

Ambary, Hasan Muarif. 1998.

Menemukan Peradaban: Jejak Arkeologis dan Historis Islam Indonesia. Jakarta: PT Logos Wacana Ilmu.

Atja dan Saleh Danasasmita. 1981.

Carita Parahiyangan. Bandung: Proyek Pengembangan Permusiuman Jawa Barat.

Ayatrohaedi. 2005.

Sundakala: Cuplikan Sejarah

Sunda Berdasarkan Naskah-

naskah Wangsakerta Cirebon.

Cetakan Pertama. Jakarta: PT

Dunia Pustaka Jaya.

Danasasmita, Saleh. 2003.

Nyukcruk Sajarah Pakuan

Pajajaran jeung Prabu Siliwangi.

Bandung: PT Kiblat Buku Utama.

Danasasmita, Saleh, et.al. 1983/1984.

Rintisan Penelusuran Masa Silam

Sejarah Jawa Barat. Jilid. 2.

Bandung: Proyek Penerbitan Buku

Sejarah Jawa Barat, Pemerintah Propinsi Tingkat I JawaBarat.

Dinas Kebudayaan dan Permuseuman Provinsi Jakarta. 2003.

Jakarta Kota Juang. Jakarta: Dinas Kebudayaan dan Permuseuman Propinsi Jakarta.

Ekadjati, Edi.S. 1976.

Babad Cirebon: Edisi Brandes;

Tinjauan Sastra dan Sejarah. Bandung: Fakultas Sastra Universitas Padjadjaran. 
Haris, Tawalinuddin. 2007.

Kota dan Masyarakat Jakarta: Dari Kota Tradisional ke Kota Kolonial (Abad XVI - XVIII). Jakarta: Penerbit Wedatama Widya.

Leirissa,R.Z. 2001.

"Dari Sunda Kelapa Ke Jayakarta" dalam Beberapa Segi Sejarah Masyarakat Budaya Jakarta. Jakarta: Pemerintah Propinsi Daerah Khusus Ibukota Jakarta Dinas Museum dan Pemugaran.

Muljana, Slamet. 1980.

Dari Holotan ke Jakarta. Jakarta: Yayasan Idayu.

Rahardjo, Supratikno. 1997.

Sunda Kalapa sebagai Bandar di Jalur Sutra. Jakarta: Proyek Inventarisasi dan Dokumentasi Sejarah Nasional Direktorat Jenderal Kebudayaan Departemen Pendidikan dan Kebudayaan.

Sedyawati, Edi, et.al.. 1986/1987.

Sejarah Kota Jakarta 1950-1980. Jakarta: Departemen Pendidikan dan Kebudayaan, Direktorat Sejarah dan Nilai Tradisional, Proyek Inventarisasi dan Dokumentasi Sejarah Nasional.

Suherman, Yuyus. 1995.

Sejarah Perintisan Penyebaran Islam di Tatar Sunda (Jawa Barat). Bandung: Penerbit Pustaka.

Sunardjo, RH Unang. 1983.

Meninjau Sepintas Panggung Sejarah Kerajaan Cirebon. Bandung: Penerbit Tarsito.

Sukanto. 1954.

Dari Djakarta ke Jayakarta: Sedjarah Ibukota Kita. Jakarta: TP.
Surjomihardjo, Abdurrachman. 1999/ 2000.

Sejarah Perkembangan Kota Jakarta. Cetakan ke-4. Jakarta: Dinas Musium dan Pemugaran Propinsi Jakarta.

Susanto, Djulianto.

"Mengapa 22 Juni 1527 Ditetapkan sebagai Hari Lahir Jakarta? Kompas, Selasa 13 Juni 2006.

Suwarno, Edi.

"Perspektif Budaya: Cabdrasengkala" dalam Majalah Kebudayaan No. 16. Tahun. VIII. 1998/1999. Jakarta: Departemen Pendidikan dan Kebudayaan.

Suwendi Montana, "Informasi Kesejarahan tentang Banten" dalam Majalah Kebudayaan No. 6. Tahun. III. 1993/1994. Jakarta: Departemen Pendidikan dan Kebudayaan.

-------, "Siapa yang Dimaksud dengan Pate Quedir oleh Tom Pires" dalam Majalah Kebudayaan No. 9. Tahun V. 1995/1996. Jakarta: Departemen Pendidikan dan Kebudayaan.

The Liang Gie. 1958.

Sedjarah Pemerintahan Kota Djakarta. Djakarta: TP.

Tjandrasasmita, Uka. 2001.

Sejarah Jakarta: Dari Zaman Prasejarah sampai Batavia Tahun 1750. Jakarta: Pemerintah Propinsi Khusus Ibukota Jakarta Dinas Museum dan Pemugaran.

Vlekke, Bernard H.M. 2008.

Nusantara: Sejarah Indonesia; diterjemahkan dari judul asli "Nusantara: A History of Indonesia" oleh Samsudin Berlian. Jakarta: Gramedia. 
